Love and Other Demons, Magyar Állami Operaház Budapest 2017

Inszenierung / Staging: Silviu Purcarete

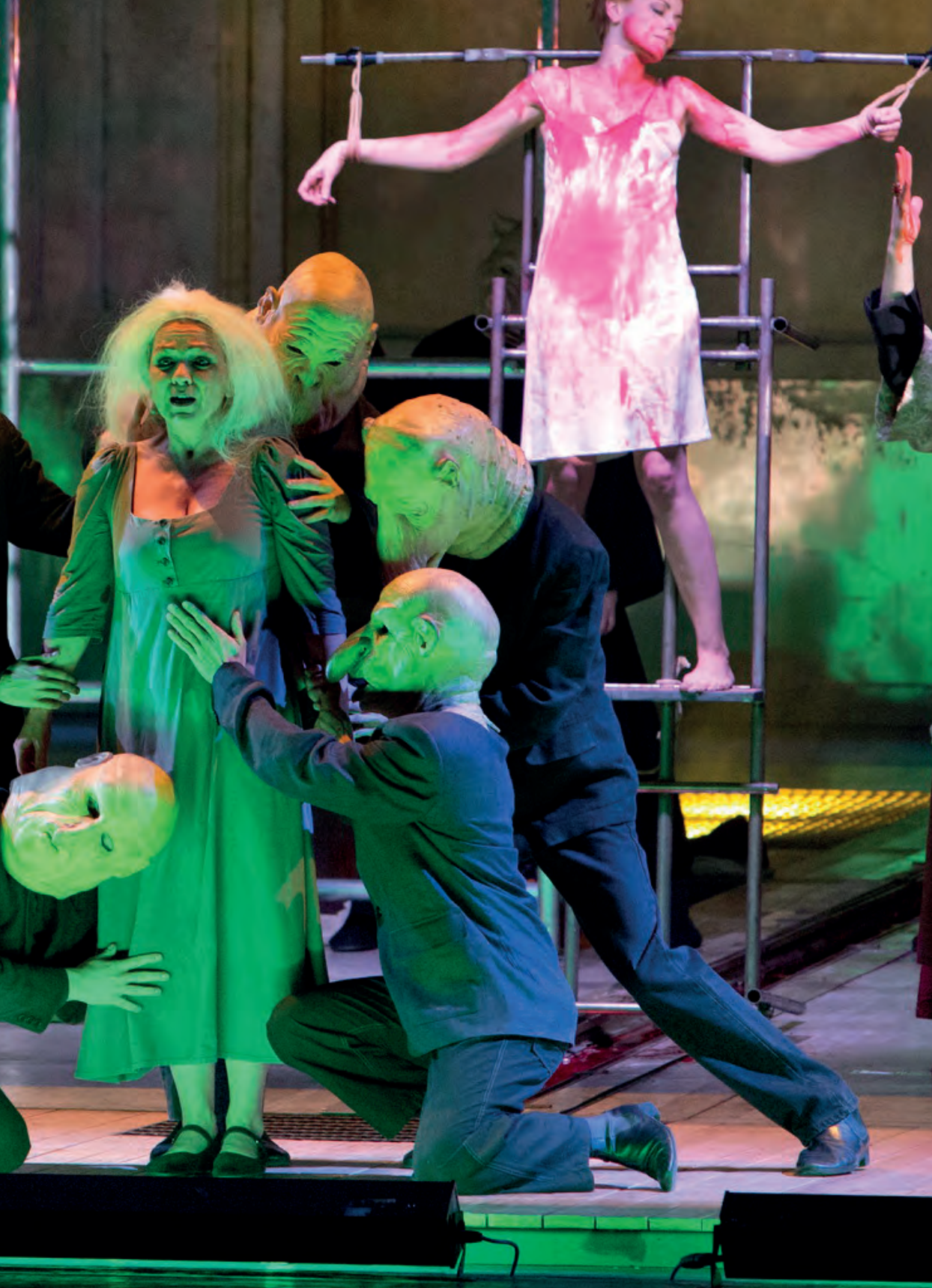




\section{Love and Other Demons}

\section{INHALT}

Sierva María, Tochter des Marquis Don Ygnacio, wächst in Cartagena de Indias ohne Mutter auf. Die schwarze Haushälterin Dominga erzieht sie, lehrt sie die Yoruba-Sprache der Sklaven und führt sie in die Welt des Voodoo ein. Während einer Sonnenfinsternis wird Sierva María auf dem Sklavenmarkt von einem offensichtlich tollwütigen Hund gebissen. Sie scheint jedoch kaum verletzt und nicht infiziert. Dominga unterzieht Sierva zur Feier ihres zwölften Geburtstags einem Voodoo-Ritual und legt ihr die Kette der Göttin Oshun, der Göttin der Liebe und Schönheit, um. Ihr Vater lehnt die heidnischen Rituale vehement ab; er will nicht, dass seine Tochter den Bräuchen der Sklaven folgt. In der Atmosphäre von Aberglaube und religiösem Wahn, die in der Stadt herrscht, ist sehr bald nicht von Tollwut die Rede, sondern davon, dass Sierva, von deren geradezu animalischer Wildheit sich viele schon lange unangenehm berührt fühlen, seit diesem Vorfall besessen sei. Obwohl der jüdische Arzt Abrenuncio weder Anzeichen von Besessenheit noch von Tollwut diagnostiziert, ordnet Bischof Don Toribio an, dass Sierva im Kloster St. Clare gefangen gesetzt und Pater Cayetano Delaura mit dem Exorzismus beauftragt wird.

Bald jedoch ist es Delaura, der besessen ist - und zwar vom "schrecklichsten aller Dämonen", von einer überwältigenden Liebe zu Sierva. Als die Äbtissin Josefa Miranda den Pater und Sierva in einer verfänglichen Situation überrascht, wirft sie ihn aus dem Kloster. Der Bischof selbst nimmt nun den Exorzismus vor, den Sierva nicht überlebt: Ihre letzten Gedanken gelten ihren Yoruba-Schutzgöttern und den spanischen Liebesgedichten Pater Delauras.

\section{KOMMENTAR}

Love and Other Demons spielt in der tropischen und magischen Welt Kolumbiens des 18. Jahrhunderts. Das Werk basiert auf dem 1994 erschiene-

\section{SYNOPSIS}

Sierva María, daughter of the Marquis Don Ygnacio, grows up without a mother. She is brought up by the black housekeeper Dominga who also teaches her the Yoruba language of the slaves and introduces her to the world of voodoo. During an eclipse of the sun, Sierva María is bitten by an apparently rabid dog at the slave market in Cartagena de Indias, but seems to be barely injured and certainly not infected. In celebration of Sierva's twelfth birthday, Dominga performs a voodoo ritual on her and gives her a necklace to wear depicting Oshun, the god of love and beauty. Her father vehemently opposes these heathen rituals; he does not wish his daughter to adhere to the customs of the slaves. Within the atmosphere of superstition and religious mania prevalent in the town, the subject of rabies has soon been dropped; the inhabitants have long been unnerved by Sierva's almost animalistic ferocity and now maintain that she has been possessed since the incident with the dog. Although the Jewish doctor Abrenuncio can detect no signs of either rabies or bedevilment, Bishop Toribio orders that Sierva should be incarcerated in the nunnery of St. Clare and orders Father Cayetano Delaura to perform her exorcism.

Soon however, it is Delaura who is possessed namely by the 'most terrible of all demons', an overwhelming love of Sierva. When Abbess Josefa Miranda discovers the Father and Sierva in a compromising situation, she throws him out of the nunnery. It is the Bishop who now performs the exorcism which Sierva does not survive: her dying thoughts are of the protective gods of the Yoruba and the Spanish love poems by Pater Delaura.

\section{COMMENTARY}

Love and Other Demons takes place in the magically tropical world of Columbia in the eighteenth century. The opera is based on the novel 'Del amor 
nen Roman "Del amor y otros demonios" (Von der Liebe und anderen Dämonen) des kolumbianischen Literaturnobelpreisträgers Gabriel García Márquez. Das Libretto schrieb der ungarische Autor Kornél Hamvai; der englische Dramaturg Edward Kemp bearbeitete zusammen mit Peter Eötvös die englischen Textpassagen.

Eine Besonderheit von Love and Other Demons ist die Aufteilung des Orchesters im Graben: Zwei identische Instrumentengruppen (jeweils Streicher, solistische Bläser und ein Schlagzeuger) sind rechts und links positioniert. In der Mitte sind Bassklarinette, Saxophon, Tuba, Harfe und Celesta platziert. Sie fungieren als klangliche Brücke zwischen den flankierenden, dialogisierenden Orchestergruppen. Zugleich setzen sie musikalisch-dramaturgische Akzente, wie beispielsweise die Celesta, mit deren Klängen die Oper beginnt und endet, oder die Tuba, die die Exorzismusszene begleitet.

Eine weitere Besonderheit ist die Mehrsprachigkeit des Librettos. Peter Eötvös und Kornél Hamvai haben den verschiedenen Erzähl- und Handlungsebenen der Geschichte ihre jeweils charakteristische Sprache gegeben: Englisch ist die Alltagssprache der Adligen, Latein ist die Sprache der kirchlichen Riten, Spanisch wird immer dann von Delaura benutzt, wenn seine Gespräche mit Sierva persönliche Empfindungen berühren und Yoruba ist die Sprache der Sklaven. y otros demonios' (Of Love and Other Demons, published in 1994) by the Columbian winner of the Nobel Prize for Literature, Gabriel García Márquez. The libretto was compiled by the Hungarian author Kornél Hamvai and the English dramatist Edward Kemp cooperated with Peter Eötvös on the English passages of the text.

A special feature of Love and Other Demons is the seating of the orchestra in the pit: two identical instrumental groups (each consisting of strings, solo wind players and a percussionist) are positioned left and right framing the central group consisting of bass clarinet, saxophone, tuba, harp and celesta. This central group functions as a tonal bridge linking the outer dialogues between the other two orchestral groups. Instruments from the centre group are also employed to highlight particular musicaldramatic moments such as the celesta with which the opera begins and ends and the tuba which accompanies the exorcism scene.

The multilingualism of the libretto is a further special feature. Peter Eötvös and Kornél Hamvai have allotted a particularly characteristic language to each of the different narratives and actions in this story: English is the daily language used by the aristocracy, Latin is the language for the ecclesiastical rituals, Delaura reverts to Spanish when his conversations with Sierva take on a personal note and Yoruba is the language of the slaves.

\section{WERKINFORMATIONEN / FACTS}

\section{Love and Other Demons}

Opera in two parts (2006-2008, rev. 2016)

Libretto by Kornél Hamvai

after Gabriel García Márquez's novel "Of Love and Other Demons"

(engl.-yoruba-lat.-span.)

Commissioned jointly by Glyndebourne Opera and the BBC

Personen / Cast: Sierva María - Koloratursopran - Don Ygnacio, a Marquis, her father - Tenor - Dominga, a black servant woman - Alt - Abrenuncio, a doctor - Tenor - Don Toribio, bishop - Bass - Father Cayetano Delaura - Bariton - Josefa Miranda, abbess - Mezzosopran - Martina Laborde, an insane woman . Alt - 5 African Slaves in Ygnacio's house - tiefe, starke Sprechstimmen / low, strong speaking voices Choir (Nuns, Slaves, Dreamvoices) · 4 Soprane, 2 Mezzosoprane, 2 Alt mit "voix blanche" 
Orchester / Orchestra: 2 (beide auch Picc., 2. auch Altfl.) $\cdot 2 \cdot 2 \cdot$ Bassklar. - Sax. (Sopran, Alt, Bariton) . 2 (2. auch Kfg.) - 4 · 2 2 2 1 - S. (I: P. [t.] · Glsp. · Crot. · Marimba · Röhrengl. · 3 Gongs · Kuhgl. · Trgl. · Beck. [m./t.] · Sizzle-Beck. · Schellen [h. u. laut, 3-4 exotische Sorten, farbiger Klang] · Tamt. [t.] · Amboss . Tamb. · gr. Tr. · Holzbl. [sehr h.] · afrik. Bohnenrassel; II: P. [t.] · Crot. · Vibr. · Röhrengl. · 4 Gongs · 2 Cencerros [sehr h.] · Trgl. · Beck. [m./t.] · Sizzle-Beck. Schellen [h. u. laut, 3-4 exotische Sorten, farbiger Klang] · Tamb. · gr. Tr. · Mar. [h./t.]) (2 Spieler) - Hfe. · Cel. - Str. (12 · $0 \cdot 8 \cdot 6 \cdot 4$ [2 mit 5. Saite H])

Bläser, Schlagzeug und Streicher sind gleichmäßig in 2 Gruppen (I./r. im Graben) aufgeteilt. Bassklar., Sax., Tb., Hfe. und Cel. sind dazwischen positioniert. Backstage sind 8 Lautsprecher aufgestellt, für deren Steuerung ein Toningenieur erforderlich ist. Eine Zuspiel-CD ist Teil des Aufführungsmaterials /

Wind instruments, percussion and string sections are divided into 2 groups and positioned in the pit (left side / right side) with bass clarinet, trombone, harp and celesta between the two groups. 8 loud-speakers are positioned backstage; a sound engineer is required for balancing the sound. A sound CD is part of the hire material.

120

\section{AUFFÜHRUNGEN / PERFORMANCES}

Uraufführung / World premiere: 10 Aug 2008 Lewes, Glyndebourne Opera (UK) · Glyndebourne Festival 2008 - London Philharmonic Orchestra · Dirigent / Conductor: Vladimir Jurowski - The Glyndebourne Chorus . Inszenierung / Staging: Silviu Purcarete · Chor / Chorus: Thomas Blunt · Bühnenbild und Kostüme / Stage and Costume Design: Helmut Stürmer

Litauische Erstaufführung / Lithuanian premiere: 7 Nov 2008 Vilnius, Lithuanian National Opera (LT) . Gaida Festival 2008 - Dirigent / Conductor: Alejo Pérez · Inszenierung / Staging: Silviu Purcarete · Bühnenbild und Kostüme / Stage and Costume Design: Helmut Stürmer - Coproduction of the Glyndebourne Festival and the Lithuanian National Opera and Ballet Theatre

Deutsche Erstaufführung / German premiere: 31 Jan 2009 Chemnitz, Opernhaus (D) · Dirigent / Conductor: Frank Beermann - Inszenierung / Staging: Dietrich Hilsdorf - Chor / Chorus: Mary Adelyn Kauffman / ThomasMichael Gribow · Bühnenbild / Stage Design: Dieter Richter - Kostüme / Costume Design: Renate Schmitzer 29 Apr 2010 Köln, Oper (D) · Dirigent / Conductor: Markus Stenz · Inszenierung / Staging: Silviu Purcarete · Chor / Chorus: Andrew Ollivant · Bühnenbild und Kostüme / Stage and Costume Design: Helmut Stürmer · Coproduction of the Glyndebourne Festival and the Lithuanian National Opera and Ballet Theatre

Französische Erstaufführung / French premiere: 25 Sep 2010 Strasbourg, Opéra National du Rhin (F) · Festival Musica 2010 - 9 Oct 2010 Mulhouse, La Filature (F) - Dirigent / Conductor: Peter Eötvös, Ralf Sochaczewsky . Inszenierung / Staging: Silviu Purcarete - Bühnenbild und Kostüme / Stage and Costume Design: Helmut Stürmer . Coproduction of the Glyndebourne Festival and the Lithuanian National Opera and Ballet Theatre

1 Jun 2013 Bremerhaven, Theater (D) · Dirigent / Conductor: Stephan Tetzlaff · Inszenierung / Staging: Andrej Woron - Ko-Regie und Choreographie / Co-Director and Choreography: Lars Scheibner · Chor / Chorus: Ilia Bilenko · Bühnenbild und Kostüme / Stage and Costume Design: Andrej Woron

Ungarische Erstaufführung / Hungarian premiere: 27 January 2017 · Budapest, Magyar Állami Operaház (H) . Dirigent / Conductor: Peter Eötvös · Inszenierung / Staging: Silviu Purcarete · Bühnenbild und Kostüme / Stage and Costume Design: Helmut Stürmer 